\title{
Chemical, physical, microbiological and quality attributes studies on River Nile crayfish
}

\author{
Emad M. El-Kholie ${ }^{1,2 \star}$, Seham A. Khader ${ }^{2}$ and Mohammed A. T. Abdelreheem ${ }^{3}$ \\ ${ }^{1}$ Research Center, College of Science, King Saud University Riyadh, Kingdom of Saudi Arabia. \\ ${ }^{2}$ Nutrition and Food Science Department, Faculty of Home Economics, Minufiya University, Egypt. \\ ${ }^{3}$ Biochemistry Depatment, Faculty of Agriculture, Ain Shams University, Cairo, Egypt.
}

Accepted 10 April, 2012

\begin{abstract}
In Egypt, red crayfish has become an important new food source, a cheap and popular source of aquatic food, replacing the expensive marine crustaceans. Chemical, physical, microbiological and quality attributes of red crayfish samples were determined. Results show that total weight of inedible parts was $\mathbf{8 4 . 6 4 \%}$ of the live weight. Value of raw fresh crayfish yield was higher than that boiled. Cooking loss tail meat for boiled crayfish was $33.88 \%$ of meat. Moisture, protein and ash contents of raw fresh red crayfish (\%) were slightly higher than those of boiled, while fat, fiber and carbohydrates contents (\%) were higher than those of raw fresh. Crayfish is considered as a good source for minerals. Amino acids content for raw fresh crayfish was relatively high and the reverse was recorded for boiled crayfish. In conclusion, the boiled red crayfish had better quality attributes than that of raw fresh.
\end{abstract}

Key words: Red swamp crayfish, chemical composition, physical properties, microbiological aspects and quality attributes.

\section{INTRODUCTION}

Procambarus clarkii is considered the most important crayfish of the 400 species known in the world, and has been successfully introduced to all countries, except, Antarctica and Australia since it is highly prolific and tolerant to poor water quality (Masser and Rouse 1997).

In recent years, aquaculture has been the fastest growing primary production industry worldwide, amounting to 39.4 million tons in 1998 (Tacon and Forster, 2000). In Egypt however, the present stock of crayfish was found to be promising although average annual yield under exploitation was estimated to be about 4.6 tons only (Emam and Khalil, 1995).

The quality of crayfish meat deteriorates due to the release of proteolytic enzymes from the digestive gland. Generally, transfer of live specimens to a country where they are not native is prohibited (Nyström, 2002).

*Corresponding author. E-mail: dr_emadelkholie@yahoo.com. Tel: +9664676080 . Fax: $+966467 \overline{3} 14$
Crayfish have been firstly found in Egypt during early 1980s. Ibrahim et al. (1995) established the presence of viable populations in the aquatic ecosystems of Giza, Cairo and some Nile delta governorates. Reynolds and Souty-Grosset (2011) reported 620 species which includes at least 440 Cambaridae, the family to which Red swamp crayfish belong. The most abundant crayfish is $P$. clarkii which had been introduced to Egyptian Nile water; this species is a polytrophic crustacean that can serve as an effective organism in controlling species composition of fresh water ecosystem (Ibrahim et al., 1995).

The crayfish's active season began in late March when temperature increased $\left(22^{\circ} \mathrm{C}\right)$ and water levels in different channels and ditches are higher (after winter closure). Therefore, the growth rate of crayfish in Egypt is higher than that of the USA which is possibly due to relatively low temperature in USA (Ibrahim et al., 1996).

In Egypt, as well as, in other countries, the red crayfish, $P$. clarkii most certainly has become an important new food source, and in some local fish markets, a cheap and 
popular source of aquatic food, replacing the expensive marine crustaceans (Ibrahim et al., 1995).

Presently, there are no established crayfish processing procedures, therefore blanch times vary considerably. If the enzymes in hepatopancreas are not inactivated by blanching, the presence of this tissue in packages of fresh crayfish meat could cause mushiness (Lodge et al., 2000; Kong et al., 2007). They also mentioned that crayfish hepatopancreas is a rich source of proteolytic enzymes. They also reported that the incidence of health related bacteria in crayfish products; however, no studies have been described in the literature on spoilage bacteria in commercially processed crayfish.

This work was conducted to study the chemical composition, physical properties, quality attributes, and microbiological aspects of red crayfish samples.

\section{MATERIALS AND METHODS}

\section{Source of crayfish}

Red swamp crayfish between 6 to $8 \mathrm{~cm}$ in total length and 40 to 50 $\mathrm{g}$ in weight obtained from the River Nile were purchased from fishermen in October to December 2010 and transferred by ice box immediately to the laboratory.

\section{Preparation of crayfish}

The crayfish samples were placed in boiling water for $5 \mathrm{~min}$ and cooled directly in iced water, then divided into two groups. The first group had the whole crayfish while, the second group, the tail was separated to be as a tail of crayfish. Each group was packaged in polyethylene bags and stored in deep freezer $\left(-18^{\circ} \mathrm{C}\right)$ for analysis. From the tail of first group, flesh was obtained by peeling the tail and the tail flesh of both two groups were subjected to chemical and microbiological analysis.

\section{Chemical analytical methods}

Moisture, protein $(\mathrm{N} \times 6.25)$, fat, fiber and ash were determined according to the methods recommended by A. O. A. C. (2000).

\section{Carbohydrates and energy value}

Carbohydrates were calculated as follows:

$\%$ carbohydrates $=100-(\%$ moisture $+\%$ protein $+\%$ fat $+\%$ ash $+\%$ fiber)

Energy value was estimated by multiplying protein and carbohydrates by 4.0 and fat by 9.0 according to the methods recommended by A. O. A. C. (2000).

\section{Amino acids determination}

Amino acids were determined according to the method described by Pellett and Young (1980), which was carried out as follows: a known weight of each sample, containing $100 \mathrm{mg}$ protein, was hydrolyzed in sealed evacuated Pyrex tube with $10 \mathrm{ml}$ of $6 \mathrm{~N} \mathrm{HCl}$ at $110^{\circ} \mathrm{C}$ for $24 \mathrm{~h}$. The hydrolyzate was filtered and completed to 100 $\mathrm{ml}$ with distilled water. Then $5 \mathrm{ml}$. of the hydrolyzate were evaporated to dryness in a rotary evaporator.

Amino acids were determined by using a LKB 4151 Alpha plus amino acids analyzer. In the Central Laboratory, Food Science Department, Faculty of Agriculture, Cairo University, results were calculated using a KB 2220 recording integrator.

\section{Tryptophan determination}

Tryptophan was determined calorimetrically after alkaline hydrolysis with $14 \%$ barium hydroxide according to the method of Blauth et al. (1963). Measurements were carried out spectrometrically at 545 $\mathrm{nm}$.

\section{Evaluation of nutritional value}

Essential amino acids index (E.A.A.I.) in relation to egg protein was determined as described by Oser (1959). Biological value (B.V.) of protein was calculated as follows:

B.V. $=1.09 \times \mathrm{EAAI}-11.73$

While, protein efficiency ratios (PER) was calculated as described by Alsmeyer et al. (1974).

\section{Determination of thiobarbituric acid number (T. B. A.)}

Thiobarbituric acid number was determined as described by Pearson (1970) and calculated by multiplying the absorbency by the factor (7.8) and the results were presented as grams of malonaldehyde / kg sample.

\section{Determination of amino nitrogen (AN)}

Amino nitrogen content was determined using the mol volumetric titration method as described by Kolochov (1952).

\section{Total volatile basic nitrogen (TVB-N)}

TVB-N was determined in $10 \mathrm{~g}$ of minced sample by macro distillation method proposed by Pearson (1976). The results were calculated as mg TVB-N / $100 \mathrm{~g}$ dry sample.

\section{Trimethylamine nitrogen (TMA-N)}

TMA-N was determined using the standard method as described by the AOAC (1995). The results were calculated as mg TMA-N / 100g dry sample.

\section{Determination of $\mathrm{pH}$ value and acidity}

The $\mathrm{pH}$ value was measured in samples according to the method described by Krilova and Liskovskaia (1961) using a Beckman pH meter with a combined electrode and acidity was determined according to Keeton and Melton (1978). 
Table 1. Average weight composition of red crayfish of the River Nile water.

\begin{tabular}{lcc}
\hline Part & Weight $\mathbf{( g )}$ & \% Total weight \\
\hline Total weight & 47.53 & - \\
Head & 5.70 & 11.99 \\
Two chelipeds & 16.20 & 34.08 \\
Carapace & 1.48 & 3.11 \\
Legs & 2.82 & 5.93 \\
Gut & 8.23 & 17.32 \\
Other hard parts & 3.45 & 7.26 \\
Tail & 9.65 & 20.30 \\
Tail meat & 7.30 & 15.36 \\
\hline
\end{tabular}

\section{Determination of physical properties}

Water holding capacity (WHC) and plasticity were measured as described by Soloviev (1966). Cooking loss was calculated as percentage of original weight as follows:

Fresh sample weight - fried sample weight

Cooking loss $\%=\frac{\text { Fresh sample weight }}{\text { F }}$

Microbiological methods

Preparation of crayfish samples for microbiological investigation

Ten grams of each fresh and boiled individual tails samples were homogenized with $90 \mathrm{ml}$ of distilled water to give 0.1 dilutions. Then different dilutions $\left(1: 10^{-1}\right.$ to $\left.1: 10^{-6}\right)$ were prepared to be used for microbiological tests.

Staphylococcus aureus determined on Paird parker agar base media according to the method described by ICMSF (1996), while molds and yeast, enumerated in potato dextrose agar (ICMSF, 1996), coliform bacterial (Oxoid) enumerated on Endo agar media (World Health Organization (WHO), 1988), Salmonella sp. determined on Salmonella shigella (SS) agar modified Oxoid according to Bryan (1991) and Bacillus cereus enumerated on $B$. cereus selective agar medium with supplement SR99 according to Roberts (1991).

\section{RESULTS AND DISCUSSION}

\section{Weight composition of red crayfish}

Weight composition of crayfish is an important consideration in determining the final cost of a given product to evaluate crayfish as human food, and to ensure that all parts are processed in rational way. Data presented in Table 1 show weight composition of tested red crayfish which were obtained from River Nile water. It is clear to notice that the average weight of red crayfish as live weight was $47.53 \mathrm{~g}$. Data also shows that the total weight of inedible parts was about $40.23 \mathrm{~g}$, being $84.64 \%$ of the live weight. These results are in agreement with those obtained by Meyers (1987).

The obtained results from Table 1 also indicate that the yield of raw tail meat of crayfish was about $15.36 \mathrm{~g}$. Similar results were obtained by Huner and Romaire (1990). Yield of red crayfish flesh varied considerably depending on species, period of intensive feeding, time of capture and amount of separated wastes (Zaitsev et al., 1969).

Also, the weight of capture carapace was $1.48 \mathrm{~g}$ being $3.11 \%$ of the total weight, which can be used to distinguish the species of crayfish as discussed by Ibrahim et al. (1995). They mentioned that two halves of carapace (covering the upper surface) which are very distinct in white crayfish (Procambarus zanangulus) are vague for red crayfish $(P$. clarkii).

Data given in Table 2 shows the effect of boiling for 5 min on the yield and cooking loss of the tested tail meat red crayfishes of the River Nile water. The obtained data shows that the average yield (tail meat weight) of raw fresh and boiled red crayfish were 7.30 and $4.95 \mathrm{~g}$, respectively.

Also, it could be observed that the value of raw fresh crayfish yield was higher than that of boiled crayfish. This is due to the effect of boiling resulting to decreasing meat yield depending on the quality of precooking samples.

Also, values of cooking loss in tail meat determined for boiled crayfish was $2.4 \mathrm{~g}$ (33.88\% of meat). This cooking loss was due to more leakage of meat juice of the crayfish upon cooking as reported by Marshall et al. (1987).

\section{Chemical composition of raw and boiled red crayfish of River Nile}

The chemical composition of raw and boiled red crayfish of the River Nile on wet weight basis are given in Table 3. It is clear to notice that the moisture and ash contents of raw fresh red crayfish (\%) were slightly higher than those 
Table 2. Effect of boiling on yield and cooking loss of tail meat tested on red crayfish of the River Nile water.

\begin{tabular}{lcc}
\hline Index & Fresh raw crayfish & Boiled crayfish \\
\hline Yield $(\mathrm{g})$ & 7.30 & 4.95 \\
Percentage of raw tail sample & - & 67.81 \\
Cooking loss $(\mathrm{g})$ & - & 2.40 \\
Percentage of meat & - & 32.88 \\
\hline
\end{tabular}

Table 3. Chemical composition of tested red crayfish of the River Nile waters (on wet weight basis).

\begin{tabular}{lllll}
\hline \multirow{2}{*}{ Ingredient } & \multicolumn{2}{l}{ Fresh raw crayfish } & \multicolumn{2}{l}{ Boiled crayfish } \\
\cline { 2 - 5 } & W/W (\%) & D/W (\%) & W/W (\%) & D/W (\%) \\
\hline Moisture & 76.60 & - & 75.40 & - \\
Protein & 19.77 & 84.50 & 19.54 & 81.10 \\
Fat & 1.99 & 8.50 & 3.45 & 13.76 \\
Ash & 1.45 & 6.20 & 1.22 & 5.00 \\
Fiber & 0.12 & 0.50 & 0.24 & 0.097 \\
Carbohydrates & 0.07 & 0.30 & 0.15 & 0.043 \\
Energy values (K kcal/ 100 g) & 97.27 & - & 109.61 & - \\
\hline
\end{tabular}

WN, Wet weight; D/W, dry weight.

of boiled crayfish samples. Values were 76.60 and $75.40 \%$, respectively. The value of protein content (percent) of raw fresh crayfish was also slightly higher than that of boiled crayfish sample. Values were 19.77 and $19.54 \%$, respectively. This may be due to escape of more protein, possibly from the porous and soft texture of boiled red crayfish meat sample.

On the other hand, fat, fiber and carbohydrates contents (percent) of boiled red crayfish were higher than those of raw fresh red crayfish sample. Fat values were 3.45 and $1.99 \%$, fiber 0.24 and $0.12 \%$ and carbohydrates 0.15 and $0.07 \%$, respectively. These results are in agreement with that reported by Sriniras et al. (1974). Moreover, more pronounced loss of protein from boiled red crayfish resulted to increased content of both fat and fiber compared to raw crayfish. Also, the more porous structure of boiled red crayfish possibly may be the reason for more entrained water when compared with raw fresh red crayfish sample. Nevertheless, this excess water may not be bound in tissue which can be checked during determination of water holding capacity (WHC) of both samples.

\section{Minerals content of the River Nile red crayfish}

Data presented in Table 4 shows mineral content of red crayfish of River Nile as mg / $100 \mathrm{~g}$ sample on wet weight basis and loss of minerals after boiling (percent). The obtained data shows that minerals content of raw fresh red crayfish samples was higher than that of boiled red crayfish. Values for sodium were 219.0 and $194.0 \mathrm{mg} /$ $100 \mathrm{~g}$, potassium 198.0 and $173.0 \mathrm{mg} / 100 \mathrm{~g}$, calcium 150.0 and $136.0 \mathrm{mg} / 100 \mathrm{~g}$, phosphorus 132.0 and 118.0 $\mathrm{mg} / 100 \mathrm{~g}$, magnesium 56.0 and $49.0 \mathrm{mg} / 100 \mathrm{~g}$, iron (0.83 and $0.76 \mathrm{mg} / 100 \mathrm{~g}$ ), copper 0.45 and $0.39 \mathrm{mg} /$ $100 \mathrm{~g}$ and zinc 2.48 and $2.21 \mathrm{mg} / 100 \mathrm{~g}$ of raw fresh and boiled red crayfish samples, respectively.

Data also observed that boiling process decreased the lead and mercury contents of red crayfish samples from 0.55 to $0.50 \mathrm{mg} / 100 \mathrm{~g}$ and from 038 to $0.33 \mathrm{mg} / 100 \mathrm{~g}$ from raw fresh and boiled red crayfish samples, respectively. The percentages of loss were 9.09 and $13.16 \%$, respectively. The results are in agreement with the results reported by Salama (1983) who mentioned pronounced loss of minerals content in steamed fish samples.

The obtained results in Table 4 reveal that crayfish may be considered as a good source for minerals, where the major minerals were $\mathrm{Na}, \mathrm{K}, \mathrm{Ca}, \mathrm{P}$ and $\mathrm{Mg}$ were found at relatively high levels. On the other hand, the heavy metals such as $\mathrm{Fe}, \mathrm{Cu}, \mathrm{Zn}, \mathrm{Pb}$ and $\mathrm{Hg}$ were found at low levels. FDA (1978) established maximum permissible limits for mercury $(0.5 \mathrm{ppm})$, lead (2.0 ppm), zinc (40.0 $\mathrm{ppm}$ ) and copper (20.0 ppm) based on the wet sample as reported by Davis (1966). Accordingly, samples of crayfish meat were far away from being toxic.

\section{Amino acids composition of raw fresh and boiled red crayfish}

Data given in Table 5 shows the amino acid composition 
Table 4. Mineral content of the River Nile red crayfish (mg / $100 \mathrm{~g}$ wet sample).

\begin{tabular}{llll}
\hline Mineral & Fresh raw crayfish & Boiled crayfish & \% Loss \\
\hline Sodium & 219.0 & 194.0 & 11.42 \\
Potassium & 198.0 & 173.0 & 12.63 \\
Calcium & 150.0 & 136.0 & 9.33 \\
Phosphorus & 132.0 & 118.0 & 10.61 \\
Magnesium & 56.0 & 49.0 & 12.50 \\
Iron & 0.83 & 0.76 & 8.43 \\
Copper & 0.45 & 0.39 & 13.33 \\
Zinc & 2.48 & 2.21 & 10.89 \\
Lead & 0.55 & 0.50 & 9.09 \\
Mercury & 0.38 & 0.33 & 13.16 \\
\hline
\end{tabular}

Table 5. Amino acid composition of red crayfish from River Nile ( $\mathrm{g} / 16 \mathrm{~g}$ nitrogen and $\mathrm{g} / 100 \mathrm{~g}$ samples) on wet weight basis.

\begin{tabular}{lllll}
\hline \multirow{2}{*}{ Amino acid } & Fresh crayfish & \multicolumn{3}{l}{ Boiled crayfish } \\
\cline { 2 - 5 } & $\mathbf{g} / \mathbf{1 6}$ g nitrogen & $\mathbf{g} / \mathbf{1 0 0} \mathbf{g}$ sample & $\mathbf{g} / \mathbf{1 6} \mathbf{g}$ nitrogen & $\mathbf{g}$ / 100 g sample \\
\hline Isoleucinc $^{*}$ & 4.41 & 0.90 & 4.39 & 0.86 \\
Leucine* $^{*}$ & 8.70 & 1.79 & 8.68 & 1.78 \\
Lysine $^{*}$ & 7.60 & 1.56 & 7.59 & 1.54 \\
Methionine* $_{\text {Cystine }}$ & 2.96 & 0.62 & 2.93 & 0.59 \\
Phenylalanine* $_{\text {Tyrosine }}$ & 1.44 & 0.31 & 1.02 & 0.29 \\
Therionine* & 4.41 & 0.89 & 4.39 & 0.87 \\
Tryptophane* & 1.77 & 0.80 & 4.74 & 0.78 \\
Valine & 1.24 & 0.96 & 1.73 & 0.93 \\
Histidine & 5.71 & 0.26 & 1.22 & 0.24 \\
Arginine & 1.98 & 1.16 & 5.68 & 1.13 \\
Alanine & 7.90 & 0.12 & 1.96 & 0.10 \\
Aspartic acid & 5.02 & 1.64 & 7.81 & 1.51 \\
Glutamic acid & 11.43 & 1.02 & 4.75 & 0.82 \\
Glycine & 15.33 & 2.34 & 11.40 & 2.30 \\
Proline & 4.47 & 3.16 & 15.30 & 3.13 \\
Serine & 3.09 & 0.91 & 4.44 & 0.88 \\
E.A.A.I & 5.12 & 0.75 & 2.79 & 0.72 \\
B.V (\%) & 85.86 & 1.05 & 5.10 & 0.85 \\
PER & 94.14 & - & 80.36 & - \\
\hline
\end{tabular}

E.A.A.I., Essential amino acids index; B.V. biological value; PER, protein efficiency ratios.

( $\mathrm{g} / 16 \mathrm{~g} \mathrm{~N}$ and as $\mathrm{g} / 100 \mathrm{~g}$ samples) of raw fresh and boiled red crayfish. The obtained results indicate that the amount of amino acid content for raw fresh red crayfish was relatively high and the reverse was recorded for boiled red crayfish samples. Nevertheless, the changes in amino acids levels were little without pronounced loss of the nutritional value of protein.

Actually, the nutritional value of all red crayfish samples showed proximate value (E.A.A.I. 85 to 80 , B.V. 93 to 94 and P.E.R. 3.13 to 3.15 ) indicating the negligible effect of both death (before boiling) and boiling process on the nutritional value based on essential amino acids determination.

\section{Quality attributes of red crayfish of the River Nile}

Data presented in Table 6 shows the quality attributes of 
Table 6. Quality attributes of red crayfish of the River Nile (on dry weight basis).

\begin{tabular}{lcc}
\hline Index & Fresh raw crayfish & Boiled crayfish \\
\hline $\mathrm{pH}$ & 7.72 & 7.19 \\
Acidity $(\mathrm{mg} / 100 \mathrm{~g})$ & 1.310 & 2.492 \\
Amino nitrogen $(\mathrm{mg} / 100 \mathrm{~g})$ & 16.80 & 13.58 \\
T.V.B.N $(\mathrm{mg} / 100 \mathrm{~g})$ & 13.69 & 12.65 \\
TMA-N $(\mathrm{mg} / 100 \mathrm{~g})$ & 4.18 & 3.26 \\
TBA $(\mathrm{mg} / 100 \mathrm{~g})$ & 0.86 & 0.64 \\
\hline
\end{tabular}

T.V.B.N., Total volatile basic nitrogen; TMA-N, trimethylamine nitrogen; TBA, thiobarbuteric acid.

Table 7. Some nitrogenous compounds of red crayfish of the River Nile ( $\mathrm{mg} / 100 \mathrm{~g}$ dry weight basis).

\begin{tabular}{lcc}
\hline Index & Fresh raw crayfish & Boiled crayfish \\
\hline Total nitrogen (T.N.) & 13.76 & 12.99 \\
Non protein nitrogen (N.P.N) & 0.62 & 0.53 \\
protein nitrogen (PN) & 13.11 & 12.45 \\
\hline
\end{tabular}

tested red crayfish of the River Nile on dry weight basis. It is clear to notice that $\mathrm{pH}$ value of raw fresh crayfish was higher than that of boiled red crayfish samples. Values were 7.72 and 7.19 , respectively, while acidity showed reverse values being 1.310 and 2.492 for raw fresh and boiled red crayfish, respectively. These results are in agreement with the results reported by Wang and Brown (1983); they found that $\mathrm{pH}$ value of the cooked crayfish (scalded for $6 \mathrm{~min}$ ) was 7.94. On the other hand, a value of free amino nitrogen of raw fresh red crayfish samples was higher than that of boiled red crayfish samples. Values were 16.8 and $13.58 \mathrm{mg} / 100 \mathrm{~g}$, respectively.

The amino nitrogen content of the tested red crayfish samples appeared to be less than allowance $(40 \mathrm{mg} / 100$ g) as reported by ICMSF (1984). Similar results were observed regarding the changes occurred in the total volatile basic nitrogen (T.V.B.N.) levels as $\mathrm{mg} / 100 \mathrm{~g}$ which were 13.69 and $12.65 \mathrm{mg} / 100 \mathrm{~g}$, for raw and boiled red crayfish samples, respectively. The obtained results from Table 6 also indicate that $\mathrm{AN}$ and total volatile nitrogen (TVN) levels were high for raw fresh red crayfish samples compared to that of boiled red crayfish samples. The decrease of AN and TVN content of boiled red crayfish samples may be due to some escape into boiling water.

In case of trimethylamine-nitrogen (TMA-N) content, the obtained data indicate that value of TMA-N was high in case of raw fresh red crayfish sample than that of boiled red crayfish sample. Values were 4.18 and 3.26 $\mathrm{mg} / 100 \mathrm{~g}$, respectively. Data also showed that TMA-N content was relatively lower than that determined by Wang and Brown (1983). The less value of TMA-N of boiled red crayfish samples than that of raw fresh may be due to leaching in boiling water.

On the other hand, thiobarbuteric acid (TBA) value of raw fresh red crayfish samples was higher than that of boiled crayfish samples. Values were 0.86 and $0.64 \mathrm{mg} /$ $100 \mathrm{~g}$, respectively. Similar results were reported by Wang and Brown (1983). They found that TBA value of fresh cooked crayfish was less than $0.4 \mathrm{mg} / 100 \mathrm{~g}$ (on wet weight basis). The foregoing results observed that the boiled red crayfish samples had better properties than raw fresh crayfish due to boiling directly after harvesting before any oxidation changes, besides the desirable effect of boiling on inhibition the oxidation awing to oxidative enzymes and bacteria.

\section{Some nitrogenous compounds of red crayfish of the River Nile}

Some nitrogenous compounds of tested red crayfish of the River Nile on dry weight basis are shown in Table 7. The boiling process also slightly reduced the content of total nitrogen (TN), non protein nitrogen (NPN) and protein nitrogen (PN). Values decreased from 13.76 to 12.99; 0.62 to 0.53 and from 13.11 to $12.45 \mathrm{mg} / 100 \mathrm{~g}$ for raw fresh and boiled red crayfish samples, respectively. This reduction is due to the loss of soluble nitrogenous compounds as reported by Sriniras et al. (1974). Also, Borgstrom (1961) mentioned that a number of non-protein nitrogenous compounds play a key role in metabolic process of marine animals and also their spoilage. 
Table 8. Physical properties of raw and cooked red crayfish of the River Nile.

\begin{tabular}{lcc}
\hline \multirow{2}{*}{ Physical property } & \multicolumn{2}{c}{ Crayfish type } \\
\cline { 2 - 3 } & Row crayfish & Blanched crayfish \\
\hline Water holding capacity $(\mathrm{WHC})\left(\mathrm{cm}^{3}\right)$ & 66.10 & 67.65 \\
Plasticity $\left(\mathrm{cm}^{3}\right)$ & 5.4 & 6.90 \\
Cooking loss $(\%)$ & 8.0 & 6.1 \\
Yield $(\mathrm{g})$ & 92.0 & 93.9 \\
\hline
\end{tabular}

Table 9. Microbiological aspects of red crayfish of the River Nile (C.F.U/g).

\begin{tabular}{lcc}
\hline Index & Fresh raw crayfish & Boiled crayfish \\
\hline Total bacterial count (T.B.C.) & $5.2 \times 10^{4}$ & $6.1 \times 10^{3}$ \\
Escherichia coli & $1.5 \times 10^{2}$ & $0.8 \times 10^{1}$ \\
Bacillus cereus & $2.5 \times 10^{2}$ & $1.4 \times 10^{1}$ \\
Staphylococcus aureus & $1.2 \times 10^{2}$ & $0.6 \times 10^{1}$ \\
Salmonella sp. & $2.4 \times 10^{2}$ & $1.5 \times 10^{1}$ \\
Mold & $3.1 \times 10^{2}$ & $1.7 \times 10^{2}$ \\
Yeast & $4.2 \times 10^{2}$ & $2.5 \times 10^{2}$ \\
\hline
\end{tabular}

\section{Physical properties of fresh raw and cooked red crayfish of the River Nile}

Data given in Table 8 shows physical properties of fresh raw and cooked red crayfish of the River Nile. It is clear to mention that boiling process increased the water holding capacity (WHC) and plasticity of red crayfish samples when compared to those of raw fresh red crayfish samples. Values of WHC and plasticity were 66.10 and $67.65 \mathrm{~cm}^{2}$ for raw fresh and 5.4 and $6.9 \mathrm{~cm}^{2}$ for boiled red crayfish samples.

The value of cooking loss of boiled red crayfish samples was $6.10 \%$, while the values of yield raw crayfish samples were higher than that of boiled samples. The values were 93.9 and $92.0 \%$ for raw fresh crayfish and boiled red crayfish samples, respectively. Similar results were reported by Godber et al. (1989).

\section{Microbiological aspects of red crayfish of the River Nile}

Data presented in Table 9 shows the microbiological aspects of tested red crayfish of the River Nile (cfu/g). The obtained data indicated that total bacterial count (TBC), Escherichia coli and B. cereus of raw fresh red crayfish were markedly higher than that of boiled red crayfish sample. The counts decreased from $5.2 \times 10^{4}$ to $6.1 \times 10^{3}, 1.5 \times 10^{2}$ to $0.8 \times 10^{1}$ and from $2.5 \times 10^{2}$ to 1.4 $\times 10^{1} \mathrm{cfu} / \mathrm{g}$ for TBC, E. coli and B. cereus, respectively. On the other hand, the same observation was recorded with S. aureus, Salmonella sp., molds and yeasts. The counts of raw fresh and boiled red crayfish samples were $1.2 \times 10^{2}$ to $0.6 \times 10^{1}, 2.4 \times 10^{2}$ to $1.5 \times 10^{1}, 3.1 \times 10^{2}$ to $1.7 \times 10^{2}$ and $4.2 \times 10^{2}$ to $2.5 \times 10^{2} \mathrm{cfu} / \mathrm{g}$, respectively. This observation was due to the effect of heat from boiling process on microorganisms (Hobbs et al., 1989).

Also, Cox and Lovell (1973) found that a TBC of fresh peeled crayfish was $1.6 \times 10^{5} \mathrm{cfu} / \mathrm{g}$. Also, Hobbs et al. (1989) found that in correlating sensory tests of cooked crayfish to bacterial number samples having aerobic plate count of $10^{7} \mathrm{cell} / \mathrm{g}$ tail meat were considered spoiled and samples with bacterial counts exceeding $10^{8} \mathrm{cell} / \mathrm{g}$ samples rated unfit for consumption.

Proteolytic, lipolytic and psychrophilic bacteria as microbiological quality indicators of raw fresh and boiled red crayfish (cfu/g) are shown in Table 10. It is clear to notice that values of proteolytic and lipolytic bacteria of boiled red crayfish were markedly lower than those of fresh raw fresh red crayfish samples.

Counts of proteolytic and lipolytic bacteria were $5.2 x$ $10^{4}$ and $2.7 \times 10^{1} \mathrm{cfu} / \mathrm{g}$ as well as $4.7 \times 10^{4}$ and $1.6 \mathrm{x}$ $10^{1} \mathrm{cfu} / \mathrm{g}$ for raw fresh and boiled red crayfish samples, respectively. On the other hand, psychrophilic bacteria were not detected in raw fresh and boiled red crayfish samples. Similar results were reported by Brown (1983) who found that in crayfish samples, the greatest residual of microbial load should be in the gut/intestinal region.

Microbial flora are confirmed to present in the digestive tract and the reason for cooking the crayfish is to reduce the chance of interior muscle and tail meat being contaminated by microorganisms and its inactive 
Table 10. Microbiological aspects (proteolytic, lipolytic and psychrophilic bacteria) of red fresh and boiled red crayfish of the River Nile (C.F.U/g).

\begin{tabular}{lcc}
\hline Tested microorganism & Fresh raw crayfish & Boiled crayfish \\
\hline Proteolytic bacteria & $5.2 \times 10^{4}$ & $2.7 \times 10^{1}$ \\
Lipolytic bacteria & $4.7 \times 10^{4}$ & $1.6 \times 10^{1}$ \\
Psychrophylic bacteria & N.D & ND \\
\hline
\end{tabular}

ND, Not detected.

endogenous enzymes.

\section{ACKNOWLEDGEMENT}

This project was supported by King Saud University, Deanship of Scientific Research, College of Science, Research Center.

\section{REFERENCES}

Alsmeyer HR, Cunningham AE, Happich ML (1974). Equation predict PER from amino acids analysis. Food Technol. July, pp. 34 - 40.

AOAC (1995). Official Methods of Analysis, Association of Official Analytical Chemists, $16^{\text {th. }}$ Ed., Virginia, U.S.A.

AOAC (2000). Association of Official Analytical Chemists, Official Methods of Analysis. $17^{\text {th. }}$ Ed., AOAC, Washington, USA, DC.

Blauth OJ, Chareinski M, Berlie H (1963). A new rapid method for determining tryptophan. Anal. Biochem. (6): 69.

Borgstrom GA (1961). Fish as food, Vol., 1: Production, Biochemistry and Microbiology. Academic Press, New York and London.

Brown EE (1983). World fish farming: cultivation and economics. Ed. 2, xviii + 516pp. ISBN 0-87055 - 427-1.

Bryan F (1991). Teaching HACCP techniques to food processors and regulatory officials, Dairy food Environ. Sant. 11: 562-568.

Cox NA, Lovell RT (1973). Identification and characterization of the microflora and spoilage bacteria in freshwater crayfish Procambarus clarkii (Girard). Journal of Food Science; 38 (4): 679 - 681.

Davis MS (1966). Food Trade Review 36, (3): 53. (C.f. Pearson, D. Chemical Analysis of Foods, $17^{\text {th }}$ Ed. Chem. Pub. Company. Inc New York .P. 70, 1970).

Emam WM, Khalil MT (1995). Pollution dynamics and stock assessment of the newly introduced crayfish (procambarus clarkia) in the river Nile Egypt. Proc. Zool. Soc. A. R. Egypt. 26: 131.

FDA (1978). Bacteriological Analysis Manual. $5^{\text {th }}$ Ed. Association of Official Analytical Chemists, Arlington, Va.

Godber JS, Wang J, Cole MT, Marshall GA (1989). Textural attributes of mechanically and cryogenically frozen whole crayfish (Procambarus clarkii). J. Food Sci. 54 (3) 564 - 566.

Hobbs HH, Jass JP, Huner JV (1989). A review of global crayfish introductions with particular emphasis on two North American species (Decapoda, Cambaridae). Crustaceana, 56: 299-316.

Huner V, Romaire RP (1990). Crawfish culture in the Southeastern USA. World Aquaculture, 21(4): 58.

Ibrahim AM, Khalil MT, Mubarek MF (1995). One the feeding behavior of the exotic crayfish procambarus clarkia in Egypt and its prospects in the bio-control of local vector snails. J. Union Arab. Biol. Zool. 4(A): 321.

Ibrahim AM, Khalil MT, Mubarek MF (1996). Ecological studies on the exotic crayfish procambarus clarkia and $P$. zonagulus in the river Nile Egypt. J. Egypt. Ger. Soc. Zool. 20 (D): 167.

ICMSF (1984). The International Commission on Microbiological
Specification for Foods Microorganisms in Foods, Univ. of Toronto, Press, Toronto, Ontario, Canada.

ICMSF (1996). The International Commission of Microbiological Specifications for Foods, Microorganisms in Foods. 5: Microbiological Specification of Pathogens, Blockie. Academic and Professional, an Imprint of Chapman \& Hall, New York.

Keeton AJT, Melton CC (1978). Factors associated with microbial growth in ground beef extended with varying levels textured soy protein. J. Food Sci. 43: 1125.

Kolochov VV (1952). Methods of Analysis of Fish and Fish Products. Food Industry Pub. Moscow.

Kong B, Xiong YL, Chen G, Webster CD (2007). Influence of gender and spawning on thermal stability and proteolytic degradation of proteins in Australian red claw crayfish (Cherax quadricarinatus) muscle stored at 2॰C. Intl. J. Food Sci. Tech. 42:1073-9.

Krilova NM, Liskovskaia MN (1961). Physico-chemical Methods for Investigation of the Products of the Animal Sources, Food industry Pub. Moscow.

Lodge DM, Taylor CA, Holdich DM, Skurdal J (2000). Reducing impacts of exotic crayfish introductions: New policies needed. Fisheries 25:21-23.

Masser MP, Rouse DB (1997). Australian red claw crayfish. SRAC publication No. 244:1-8.

Marshal G, Moody MW, Hackney CR, Godber JS (1987). Effect of blanch time on the development of mushiness in ice -stored crayfish meat packed with adhering hepatopencreas. J. Food Sci. 52(6): 1504.

Meyers P (1987). Crawfish Total product utilization. Inter. Fish Marketing Digest, (3): 187.

Nyström P (2002). Ecology In: Holdich DM (ed) Biology of Freshwater Crayfish. Black Well Science Ltd, Oxford, pp. 192 - 235.

Oser BL (1959). An Integrated Essential Amino Acid Index for Predicting the Biological Value of Protein in Protein and Amino Acid Nutrition. Ed. A. A. Albanese, Academic Press, New York.

Pearson D (1970). The Chemical Analysis of Food, National Collage of Food Technol. Univ. Reading, Webn'dge, Surry, J. A Churchill. U.K.

Pearson D (1976). Flesh Foods: Table Jellies. : The Chemical Analysis of Food. pp.383-397, Churchill Livingstone Edinburgh, London and New York.

Pellett PL, Young VR (1980). Nutritional valuation of Protein Food. Food and Nutrition Bulletin, Supplemental, Published by the United Nations Univ.

Reynolds J, Souty-Grosset C (2011). Management of freshwater Biodiversity. Crayfish as bioindicators. Cambridge Univ. Press, UK.

Roberts D (1991). Sources of Food infections, the lancet, Reinhold Publishing Corporation New York, Chapman and Hall, Lid, London, 33(6):859-861.

Salama AE (1983). Chemical and Microbiological Studies on Fish. Msc. Thesis, Fac. of Agric. Kafr Elsheikh, Tanta Univ. Egypt.

Soloviev VE (1966). Aging of Meat, Food Industry Pub. (In Rus).

Sriniras H, Vakil UK, Vasel AS (1974). Nutritional and compositional changes in de-hydro irradiated shrimp. J. Food Sci. 39: 807.

Tacon AG, Forster IP (2000). "Trends and challenges to aquaculture and aqua feed development in the new millennium", Avances en Nutrición Acuícola, Memorias del V Simposium Internacional de Nutrición Acuícola, Mérida, Yucatán, México, pp. 1-12. 
Wang MY, Brown WD (1983). Effects of elevated CO2 atmospheres on storage of fresh water crayfish (Pacifastacus leniusculus). J. Food Sci. 48 (1) $158-162$.
WHO (1988). Health Education in Food Safety. WHO/88(7):32.

Zaitesv V, Kisevetter I, Lagunov L, Makarova T, Minder L, Podsevalov, V (1969). Fish Curing and Processing. Mirpublishers, Moscow. 